\title{
HIGHER-ORDER QUASIMONOTONICITY AND INTEGRAL INEQUALITIES
}

\author{
Mihály Bessenyei ANd EVELIN PÉnZES
}

Abstract. The classical Hermite-Hadamard inequality is not merely a consequence of convexity, but also characterizes convexity. Such inequalities hold in the case of higher-order monotonicity in sense of Hopf and Popoviciu with the same characteristic feature. The aim of this note is to extend these results, when the underlying monotonicity is induced by so-called quasipolynomial Chebyshev systems.

Mathematics subject classification (2010): Primary 26A51, Secondary 26D15, 39B62, 65D32. Keywords and phrases: Chebyshev system, generalized monotonicity and convexity, quadrature formula, Hermite-Hadamard inequality.

\section{REFERENCES}

[1] M. BessenyeI, Hermite-Hadamard-type inequalities for generalized convex functions, Ph. D. dissertation (2005), J. Inequal. Pure Appl. Math. 9, 3 (2008), art. 63.

[2] M. BesSENYEI, The Hermite-Hadamard inequality in Beckenbach's setting, J. Math. Anal. Appl. 364 (2010), 366-383.

[3] M. Bessenyei And Zs. PÁLes, Higher-order generalizations of Hadamard's inequality, Publ. Math. Debrecen 61, 3-4 (2002), 623-643.

[4] M. BesSENYEI AND Zs. PÁles, Hermite-Hadamard inequalities for generalized convex functions, Aequationes Math. 69 (2005), 32-40.

[5] M. Bessenyei And Zs. PÁles, Characterization of convexity via Hadamard's inequality, Math. Inequal. Appl. 9, 1 (2006), 53-62.

[6] M. BessenYeI AND Zs. PÁLes, Characterizations of higher-order monotonicity via integral inequalities, Proc. Roy. Soc. Edinburgh Sect. A, 140 (2010), 723-736.

[7] J. HADAMARD, Étude sur les propriétés des fonctions entières et en particulier d'une fonction considérée par Riemann, J. Math. Pures Appl. 58 (1893), 171-215.

[8] G. H. Hardy, J. E. LitTlewood, And G. Pólya, Inequalities, Cambridge University Press, Cambridge, 1934 (first edition), 1952 (second edition).

[9] Ch. Hermite, Sur deux limites d'une integrale define, Mathesis 3 (1883), 82.

[10] E. HopF, Über die Zusammenhänge zwischen gewissen höheren Differenzenquotienten reeller Funktionen einer reellen Variablen und deren Differenzierbarkeitseigenschaften, Dissertation, FriedrichWilhelms-Universität Berlin, 1926.

[11] S. KARLIN AND W. J. STUDDEn, Tchebycheff systems: With applications in analysis and statistics, Pure and Applied Mathematics, vol. XV, Interscience Publishers John Wiley \& Sons, New YorkLondon-Sydney, 1966.

[12] M. KuCZMA, An Introduction to the Theory of Functional Equations and Inequalities, Państwowe Wydawnictwo Naukowe - Uniwersytet Śląski, Warszawa-Kraków-Katowice, 1985.

[13] D. S. Mitrinović And I. B. Lacković, Hermite and convexity, Aequationes Math. 28 (1985), 229-232.

[14] C. P. Niculescu And L.-E. Persson, Old and new on the Hermite-Hadamard inequality, Real Anal. Exchange 29 (2003/2004), 619-623.

[15] C. P. Niculescu And L.-E. Persson, Convex Functions and Their Applications. A Contemporary Approach, CMS Books in Mathematics, vol. 23, Springer-Verlag, New York, 2006. 
[16] T. Popoviciu, Les fonctions convexes, Hermann et Cie, Paris, 1944.

[17] A. W. Roberts and D. E. Varberg, Convex Functions, Pure and Applied Mathematics, vol. 57, Academic Press, New York-London, 1973.

[18] W. Rudin, Principles of Mathematical Analysis, 3rd ed., International Student Edition, 1976.

[19] G. Szegő, Orthogonal Polynomials, American Math. Society, Providence, Rhode Island, 1939. 